\title{
Evaluation of seismic capacity on the building law Faculty Tadulako University due to Palu earthquake 2018
}

\author{
Hamdeni Medriosa ${ }^{1,2^{*}}$ \\ ${ }^{1}$ Doctoral Student of Civil Engineering Department, Andalas University, Padang, 25163, Indonesia \\ ${ }^{2}$ Civil Engineering Department, Padang Institute of Technology, Padang, 25143, Indonesia
}

\begin{abstract}
Indonesia is located in a high level of the earthquake risk area. According to USGS data, from December 2004 to October 2009, more than ten large earthquakes occurred and exceeded 5.0 Scale Richter in magnitude. Recently, the major earthquake occurred on September 28, 2018, in Palu City, Central Sulawesi, with 7.4 on the Scale Richter in magnitude and triggered a lot of building damaged. In this study, the seismic capacity of a 3-story reinforced concrete building, which collapsed due to a large earthquake in the city of Palu, was evaluated. The Standard for Seismic Evaluation of Existing Reinforced Concrete Buildings, 2001 from Japan, was used to evaluate the seismic capacity of reinforced concrete. In this analysis only reviews the column structure elements. However, the brick wall elements are considered to determine net column height. The analysis has been done only for the first floor, where there is the maximum shear force on the structure. Seismic capacity is determined by the relationship between the lateral strength and the ductility index. The obtained results of the seismic capacity analysis showed that the total strength index value of the building was 0.307 for the north to south and 0.455 . The seismic capacity of this building is compared with the seismic capacity of a reinforced concrete building that survived due to a large earthquake with 7.6 on the Scale Richter in West Sumatra in September 2009. The obtained results show that the strength index value of this building is smaller than that of a building that could survive the 2009 West Sumatra earthquake.
\end{abstract}

\section{Introduction}

Indonesia is located in a high level of the earthquake risk area. According to USGS data, from December 2004 to October 2009, more than ten large earthquakes occurred exceed 5.0 Scale Richter and triggered a lot of damage to buildings. The resilience of buildings during earthquake loads is influenced by several things, which are the earthquake-resistant house planning standards, construction implementation, and construction planning (Liza, N. M. et al., 2014). Several major earthquakes have occurred in West Sumatra, which resulted in many reinforced concrete buildings that were damaged and collapsed (Maidiawati and Sanada 2008, EERI, 2009).[6]

Recently, the earthquake occurred in Palu City, Central Sulawesi, on September 28, 2018, with a magnitude of 7.4 SR triggered many damages on reinforced concrete buildings. The damage of the building can be classified on from minor to heavy damage and collapsed. One of them is the Tadulako University Faculty of Law Building, Palu City, Central Sulawesi. This building is a 3-story building with reinforced concrete structures that collapsed when an earthquake of 7.4 on the Richter Scale struck Palu City. The building collapsed only on the first floor, while the second and third floors did not experience such significant damage.
Based on the damage due to the earthquake, it is interesting to evaluate the performance of the seismic capacity of the reinforced concrete building (existing building) of the Faculty of Law, Tadulako University. The Standard for Seismic Evaluation of Existing Reinforced Concrete Buildings, 2001 from Japan, was used to evaluate the seismic capacity of reinforced concrete.

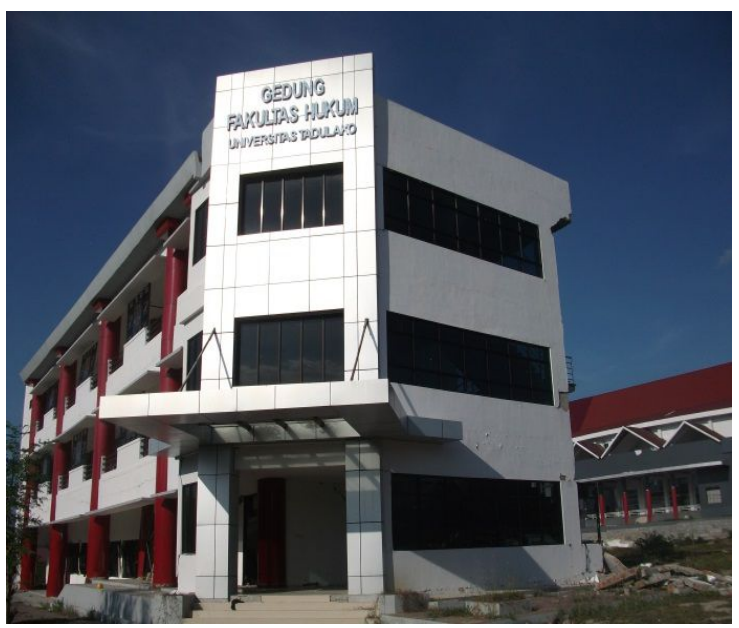

Fig. 1: Law Faculty Tadulako University

\footnotetext{
${ }^{1}$ Corresponding author: hamdenimedriosa@itp.ac.id
} 


\section{Literature review}

\subsection{State of the art}

\subsubsection{Column strength}

According to the level two methods, the building strength is reviewed vertically by the structural strength of the column. In general, the structural strength is divided into the shear strength and flexural strength.

\subsubsection{Ultimate flexural strength of column $(\mathrm{Mu})$}

Ultimate Flexural Strength of Structure $(\mathrm{Mu})$ is calculated based on equations (2.1), (2.2) or (2.3) (The Japan Building Disaster Prevention Association, 2001).

a. For $\mathrm{N}_{\max } \geq \mathrm{N}>0.4 \times$ b x D x Fc

$M u=\left\{0,8 \cdot a_{\mathrm{t}} \cdot \sigma \mathrm{y} \cdot D+0,12 b D 2 \mathrm{Fc}\right\}$

$\frac{N \max -N}{N \max -0,4 b \cdot D \cdot F c}$

(2.1)

b. For $0.4 \mathrm{~b} \times \mathrm{D} \times \mathrm{Fc} \geq \mathrm{N}>0$

$M u=\left\{0,8 \cdot \alpha_{\mathrm{t}} . \sigma_{\mathrm{y} \cdot} D+0,5 \cdot N \cdot D\right\}\left(1-\frac{N}{b . D . F c}\right)$

c. For $0>N \geq N_{\min }$

$M u=0,8 \cdot \mathrm{a}_{\mathrm{t}} \cdot \sigma_{\mathrm{y}} \cdot D+0,4 \cdot N \cdot D$

$\mathrm{Nmax}=$ b.D.Fc $+\mathrm{a}_{\mathrm{t}} . \sigma_{\mathrm{y}}$

$\mathrm{N}_{\min }=-\mathrm{a}_{\mathrm{g}} \cdot \sigma_{\mathrm{y}}$

\subsubsection{Shear strength of column when ultimate} bending (Qmu)

The column shear force on ultimate bending is calculated by equation (2.6) (The Japan Building Disaster Prevention Association, 2001).

$$
Q_{m u}=\frac{2 M u}{h_{0}}
$$

\subsubsection{The Ultimate Shear Strength Column} (Qsu)

The ultimate shear strength of the structure (Qsu) is calculated based on equation (2.7) (The Japan Building Disaster Prevention Association, 2001).

$$
\begin{aligned}
Q_{s u}=\left\{\frac{0.053 \cdot P_{t}{ }^{0.23}(18+\mathrm{Fc})}{\frac{M}{Q . d}+0.12}+0,85 \sqrt{P_{w} \cdot S . \sigma_{w}}+\right. & \left.0.1 \sigma_{0}\right\} b . j \\
P_{t} & =\frac{\alpha_{t}}{b . D} \cdot 100 \% \\
\frac{M}{Q . d} & =\frac{h_{0} / 2}{D} \\
P_{w} & =\frac{A_{v}}{b . s} \cdot 100 \% \\
\sigma_{0} & =\frac{N}{b . D}
\end{aligned}
$$

\subsubsection{Column failure type}

The collapse of a structure is determined by the ultimate shear strength (Qsu) and the ultimate flexural strength (Qmu). If the Qsu / Qmu $<1$, it is mean the collapsed form of the building is a shear collapse. The shape of the collapse of a structure is an important point to calculate the ductility of a structure. According to The Japan Building Disaster Prevention Association (2001)[7], the collapsed form of a building is used to see the ratio of building strength index.

\subsubsection{Column Strength Index (C)}

The strength index (C) in the second level calculation method can be calculated by the following equation: (The Japan Building Disaster Prevention Association, 2001)[7]

$$
C=\frac{Q_{u}}{\Sigma W}
$$

\subsection{Deformation Ultimate of Column}

The concept of deformation is a change in shape or size due to the loads. In general, compressive stress is applied to the column, due to shortening. Equation 2.13 was using to calculate that. (The Japan Building Disaster Prevention Association, 2001).

$$
\mathrm{R}_{\mathrm{mu}}=\left(\frac{h_{0}}{H_{0}}\right) \cdot{ }_{\mathrm{c}} \mathrm{R}_{\mathrm{mu}} \geq \mathrm{R}_{250}
$$

When :

$$
\begin{aligned}
& \mathrm{h} 0 / \mathrm{H} 0 \leq 1 \\
& { }_{\mathrm{c}} \mathrm{R}_{\mathrm{mu}}={ }_{\mathrm{c}} \mathrm{R}_{\mathrm{my}}+{ }_{\mathrm{c}} \mathrm{R}_{\mathrm{mp}} \\
& \mathrm{R}_{\mathrm{my}}=\mathrm{h}_{0} / \mathrm{H}_{0} \cdot{ }_{\mathrm{c}} \mathrm{R}_{\mathrm{my}} \geq{ }_{\mathrm{c}} \mathrm{R}_{250} \\
& { }_{\mathrm{c}} \mathrm{R}_{\mathrm{my}}=\mathrm{R}_{150} \text { for } \mathrm{h}_{0} / \mathrm{H}_{0} \geq 3 \\
& { }_{\mathrm{c}} \mathrm{R}_{\mathrm{my}}=\mathrm{R}_{250} \text { for } \mathrm{h}_{0} / \mathrm{H}_{0} \leq 2
\end{aligned}
$$

\subsubsection{Plastic deviation of Column}

Plastic deviation of column can be calculated with considering some part according to equation 2.18 (The Japan Building Disaster Prevention Association, 2001)[7]

$$
\begin{aligned}
& { }_{c} \mathrm{R}_{\mathrm{mp}}=10\left(\frac{c Q_{s u}}{c Q_{m u}}-q\right) \cdot{ }_{c} \mathrm{R}_{\mathrm{my}} \geq 0 \\
& (2.18) \\
& \mathrm{q}=1.0 \text { for } \mathrm{S} \leq 100 \mathrm{~mm} \\
& (2.19) \\
& \mathrm{q}=1,1 \text { for } \mathrm{S}>100 \mathrm{~mm}
\end{aligned}
$$

\subsubsection{Limit of Plastic Deviations in the Column}

The limit of plastic deviation from the column can be determined with (2.21), (2.22), (2.23), (2.24), (2.25) 
equations. (The Japan Building Disaster Prevention Association, 2001).

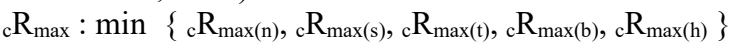

${ }_{\mathrm{c}} \mathrm{R}_{\max (\mathrm{n})}={ }_{\mathrm{c}} \mathrm{R}_{250}$ untuk $\eta>\eta_{\mathrm{H}}$

Where

$$
{ }_{c} \mathrm{R}_{\max (\mathrm{n})}={ }_{\mathrm{c}} \mathrm{R}_{30}\left({ }_{\mathrm{c}} \mathrm{R}_{250} /{ }_{\mathrm{c}} \mathrm{R}_{30}\right) \eta^{\prime} \leq{ }_{\mathrm{c}} \mathrm{R}_{30}
$$

$\eta=\left(\eta-\eta_{\mathrm{L}}\right)\left(\eta_{\mathrm{H}}-\eta_{\mathrm{L}}\right)$

$\eta=N_{s} /(b . D F c)$

$\eta_{L}=0,25$ dan $\eta_{\mathrm{H}}=0,5$ for $s \leq 100 \mathrm{~mm}$

$\eta_{L}=0,2$ dan $\eta_{\mathrm{H}}=0,4$ for $s>100 \mathrm{~mm}$

${ }_{c} R_{\max (s)}={ }_{c} R_{250}$ for ${ }_{c} \tau_{\mathrm{u}} / \mathrm{Fc}>0,2$

${ }_{c} R_{\max (s)}={ }_{c} R_{30}$

${ }_{c} R_{\max (t)}={ }_{c} R_{250}$ for $\mathrm{Pt}>1 \%$

${ }_{c} R_{\max (t)}={ }_{c} R_{30}$

${ }_{c} R_{\max (b)}={ }_{c} R_{50}$ for $\mathrm{s} / \mathrm{db}>8$

${ }_{c} R_{\max (b)}={ }_{c} R_{30}$

${ }_{c} R_{\max (h)}={ }_{c} R_{50}$ for $h_{0} / \mathrm{D} \leq 2$

${ }_{c} R_{\max (h)}={ }_{c} R_{30}$

\subsubsection{Ductility Index (F)}

Definition of ductility is the ability of a building structure to experience large post-elastic deviations repeatedly and cyclic due to the earthquake loads that cause of the first yield stage, while maintaining sufficient strength and rigidity so that the structure of the building remains to stand, even though it is already in critical condition of collapse.

Ductility index, $\mathrm{F}$ is a certain deformability which is calculated according to structural specifications based on stiffness, strength, dimensions, etc. (JBDPA, 2005). Which is determined by equations (2.26), (2.30), (2.31) (The Japan Building Disaster Prevention Association, 2001)

\section{a. Shear column}

The ductility index of the shear column is calculated using equation (2.26) based on the angle when the deformation in the building occurs. It can be translated to the ultimate deformation in the failure of the shear column (The Japan Building Disaster Prevention Association, 2001)

$$
\begin{aligned}
& F=1+0,27 \frac{R_{s u}-R_{250}}{R_{y}-R_{250}} \\
& \mathrm{R}_{\mathrm{su}}=\frac{c Q_{s u} / c Q_{m u}-1}{0,7} \cdot R_{m y} \geq R_{250} \text { for }{ }_{\mathrm{c}} \alpha, \mathrm{Q}_{\mathrm{mu}}<\mathrm{Q}_{\mathrm{su}} \\
& \mathrm{R}_{\mathrm{su}}=\mathrm{R}_{250} \text { for }{ }_{\mathrm{c}} \alpha, \mathrm{Q}_{\mathrm{mu}} \geq \mathrm{Q}_{\mathrm{su}} \\
& { }_{\mathrm{c}} \alpha=0,3+0,7\left(\mathrm{R}_{250} / \mathrm{R}_{\mathrm{my}}\right) \\
& \text { b. Bending column }
\end{aligned}
$$

The ductility index of the bending column can be calculated using equation (2.30) or (2.31) based on the angle formed on each floor of the building during the ultimate deformation in the bending failure of the column (The Japan Building Disaster Prevention Association, 2001)

(i) For case $\mathrm{R}_{\mathrm{mu}}<\mathrm{R}_{\mathrm{y}}$

$$
F=1+0,27 \frac{R_{m u}-R_{250}}{R_{y}-R_{250}}
$$

(ii)

$$
\begin{aligned}
& \text { For case } \mathrm{R}_{\mathrm{mu}} \geq \mathrm{R}_{\mathrm{y}} \\
& F=\sqrt{\frac{2 R_{m u} / R_{y}-1}{0.75\left(1+0.05 R_{m u} / R y\right)}} \leq 3.2
\end{aligned}
$$

\subsection{Effective Strength Factor ( $\alpha$ )}

The value of the effective strength factor $(\alpha)$ can be seen in table $1 . \alpha$ s is the effective strength factor of the shear column which is calculated using equation (2.32). $\alpha \mathrm{m}$ is the effective factor strength factor of the bending column which is determined using equation (2.33). Rmy is the angle of deformation that occurs when bending is calculated using equation (2.15). Rsu is the angle of deformation when the shear strength is calculated using equations (2.16) and (2.17). Q (F1) is the shear force when the deformation capacity R1 of a column in the second or higher group. Qsu is the shear strength of a column in the second group or higher. Qmu is the load when flexural yielding of a column in the second group or higher (The Japan Building Disaster Prevention Association, 2001).

$$
\begin{aligned}
& \alpha_{\mathrm{s}}=\mathrm{Q}_{(\mathrm{F} 1)} / \mathrm{Qsu}=\alpha_{\mathrm{m}} \mathrm{Q}_{\mathrm{mu}} / \mathrm{Q}_{\mathrm{su}} \leq 1.0 \\
& \alpha_{\mathrm{m}}=\mathrm{Q}_{(\mathrm{F} 1)} / \mathrm{Q}_{\mathrm{mu}}=0.3+0.7 \times \mathrm{R}_{1} / \mathrm{R}_{\mathrm{my}}
\end{aligned}
$$

\section{Methodology}

The observation was done by examining the breakdown of reinforced concrete structures in buildings. The existing compressive strength of concrete is obtained by conducting non-destructive testing using the hammer test. The reinforcement used in the damaged reinforced concrete structure is also measured as the diameter of the reinforcement used, the type of reinforcement, and the length of the dispensing. The reinforcement of the stirrups is a measurement of the distance between the stirrups and the large angle and the length of the curve in the stirrups. The analysis was carried out based on The Standard for Seismic Evaluation of Existing Reinforced Concrete Buildings published by The Japan Building Disaster Prevention Association[7]. Furthermore, the next procedure is using the Microsoft Excel program.

\section{Analysis and discussion}

\subsection{Building description}

The structural details for calculations such as column cross-section size, column details, reinforcement quality are obtained from the DED (Detail 
Engineering Design) of the building. The first-floor plan of the building is illustrated in Fig. 2

\subsection{Seismic Capacity of Reinforced Concrete Buildings}

The seismic capacity of the Tadulako University Faculty of Law building is evaluated only for the first floor, where the floor has a maximum load. The analysis is calculated in two (2) directions, from north-south direction (X direction) and east-west direction ( $\mathrm{Y}$ direction). In the analysis of the brick wall is ignored in the calculation by considering the wall as a nonstructure. The seismic capacity of a building is expressed in the relationship between the strength index and the ductility index as shown in Fig. 3.a for northsouth direction and Fig. 3.b for east-west direction. Fig. 3.a shows the collapsing stages of the north-south column. The building has a total strength index of 0.307 . At the ductility index of 0.8 , the building collapses before the plastic limit by reducing the strength index to 0.044 .

Table 1. Effective strength factors $(\alpha)$

\begin{tabular}{|c|c|c|c|c|}
\hline \multicolumn{5}{|c|}{ The value of $F_{1}$ for the first group $=0.8\left(R_{1}=R_{500}=1 / 500\right)$} \\
\hline & \multicolumn{2}{|c|}{\begin{tabular}{|c|c|c|}
$\mathrm{F}_{1}$ & \\
\end{tabular}} & \multicolumn{2}{|l|}{$\mathrm{F}_{1}=0,8$} \\
\hline & \multicolumn{2}{|l|}{$\mathrm{R}_{1}$} & \multicolumn{2}{|c|}{$\mathrm{R}_{1}=\mathrm{R}_{500}$} \\
\hline \multirow[t]{6}{*}{ First Group } & \multicolumn{2}{|l|}{ Shear $\left(\mathrm{R}_{\mathrm{su}}=\mathrm{R}_{250}\right)$} & \multicolumn{2}{|c|}{$\alpha_{\mathrm{s}}$} \\
\hline & \multicolumn{2}{|l|}{ Shear $\left(\mathrm{R}_{\mathrm{su}}<\mathrm{R}_{250}\right)$} & \multicolumn{2}{|l|}{$\alpha_{\mathrm{s}}$} \\
\hline & \multicolumn{2}{|l|}{ Bending $\left(\mathrm{R}_{\mathrm{my}}=\mathrm{R}_{250}\right)$} & \multicolumn{2}{|l|}{0,65} \\
\hline & \multicolumn{2}{|l|}{ Bending $\left(\mathrm{R}_{250}<\mathrm{R}_{\mathrm{my}}<\mathrm{R}_{150}\right)$} & \multicolumn{2}{|l|}{$\alpha_{\mathrm{m}}$} \\
\hline & \multicolumn{2}{|l|}{ Bending $\left(\mathrm{R}_{\mathrm{my}}=\mathrm{R}_{150}\right)$} & \multicolumn{2}{|l|}{0,51} \\
\hline & \multicolumn{2}{|c|}{$\begin{array}{l}\text { Shear wall dan bending } \\
\text { If in the first groun the } F_{1} \text { value }>10\left(R_{1}\right.\end{array}$} & \multicolumn{2}{|l|}{0,65} \\
\hline \multicolumn{5}{|c|}{ If in the first group, the $F_{1}$ value $>1.0\left(R_{1} \geq R_{250}=1 / 250\right)$} \\
\hline & $\mathrm{F}_{1}$ & $\mathrm{~F}_{1}=1.0$ & $1.0<\mathrm{F}_{1}<1.27$ & $1.27 \leq \mathrm{F}_{1}$ \\
\hline & $\mathrm{R}_{1}$ & $\mathrm{R}_{250}$ & $\mathrm{R}_{250}<\mathrm{R}_{\mathrm{my}}<\mathrm{R}_{150}$ & $\mathrm{R}_{250}=\mathrm{R}_{1}$ \\
\hline \multirow[t]{5}{*}{ Second Group } & Shear $\left(\mathrm{R}_{\mathrm{su}}=\mathrm{R}_{250}\right)$ & 1.0 & 0.0 & 0 \\
\hline & Shear $\left(\mathrm{R}_{\mathrm{su}}<\mathrm{R}_{250}\right)$ & $\alpha_{\mathrm{s}}$ & $\alpha_{\mathrm{s}}$ & 0 \\
\hline & Bending $\left(\mathrm{R}_{\mathrm{my}}=\mathrm{R}_{250}\right)$ & 1.0 & 1.0 & 1.0 \\
\hline & Bending $\left(\mathrm{R}_{250}<\mathrm{R}_{\mathrm{my}}<\mathrm{R}_{150}\right)$ & $\alpha_{\mathrm{m}}$ & $\alpha_{\mathrm{m}}$ & 1.0 \\
\hline & Bending $\left(\mathrm{R}_{\mathrm{my}}=\mathrm{R}_{150}\right)$ & 0.72 & $\alpha_{\mathrm{m}}$ & 1.0 \\
\hline
\end{tabular}

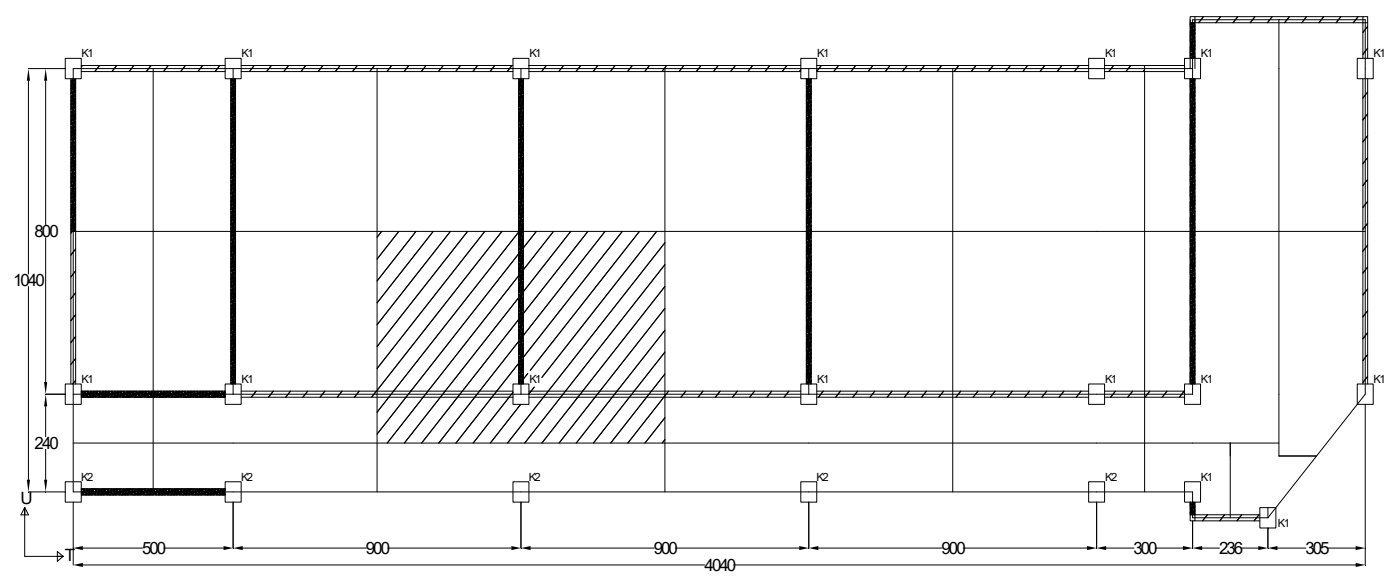

Fig. 2: The floor load area for one column

The collapsed column at the 0.8 ductility index is the shear column. This column experiences sliding collapse because there is a brick wall that locks so that it is as a short column with a net height of 1.8 meters. These columns include the $x 1-y 2$ column. The collapse of this column caused a drastic reduction in the building strength index so that the building strength index became 0.138 . Furthermore, at the 2.48 , ductility index the building collapsed again by reducing the strength index to 0.238 . The building continues to collapse the column until all columns collapse at the ductility limit of 3.2. Fig. 3.b shows the collapsing stages of the east- west column. The building has a total strength index of 0.364 . At the ductility index of 0.8 , some columns collapse before reaching the plastic limit by reducing the strength index to 0.090 . The collapsed column at the 0.8 ductility index is the shear column. This column experiences sliding collapse because there is a brick wall that locks so that it is as a short column with a net height of 1.8 meters. These columns include $\mathrm{x} 1-\mathrm{y} 3$ and $\mathrm{x} 2-\mathrm{y} 3$ columns. The collapse of this column caused a drastic reduction in the building strength index so that the building strength index became 0.223 . 


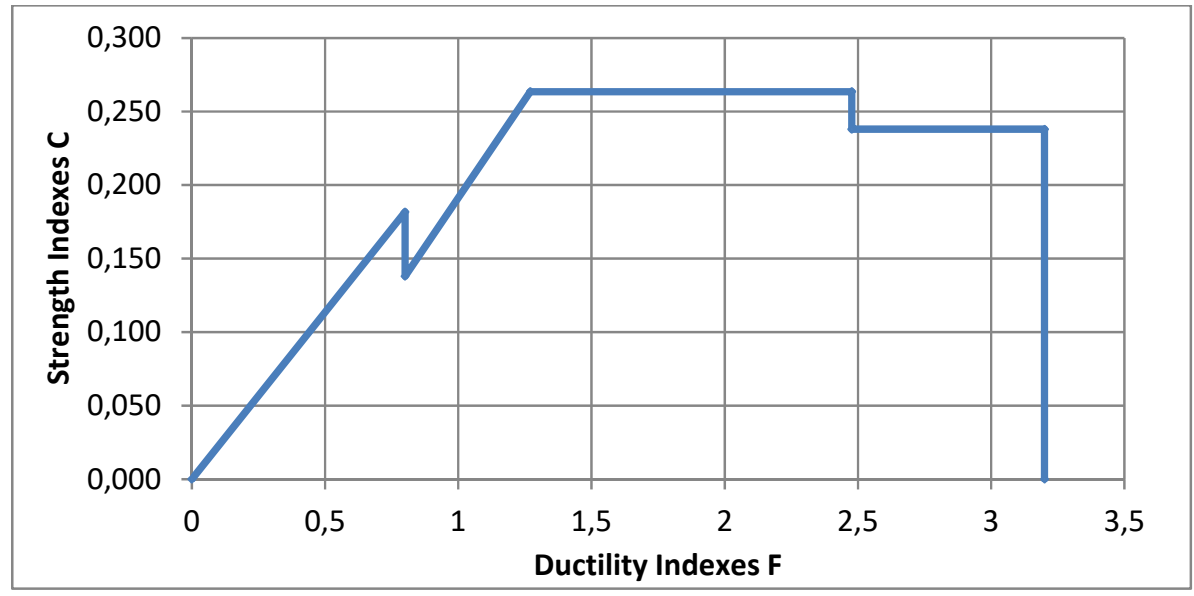

a. Relationship between Index C and F in the North-South Direction

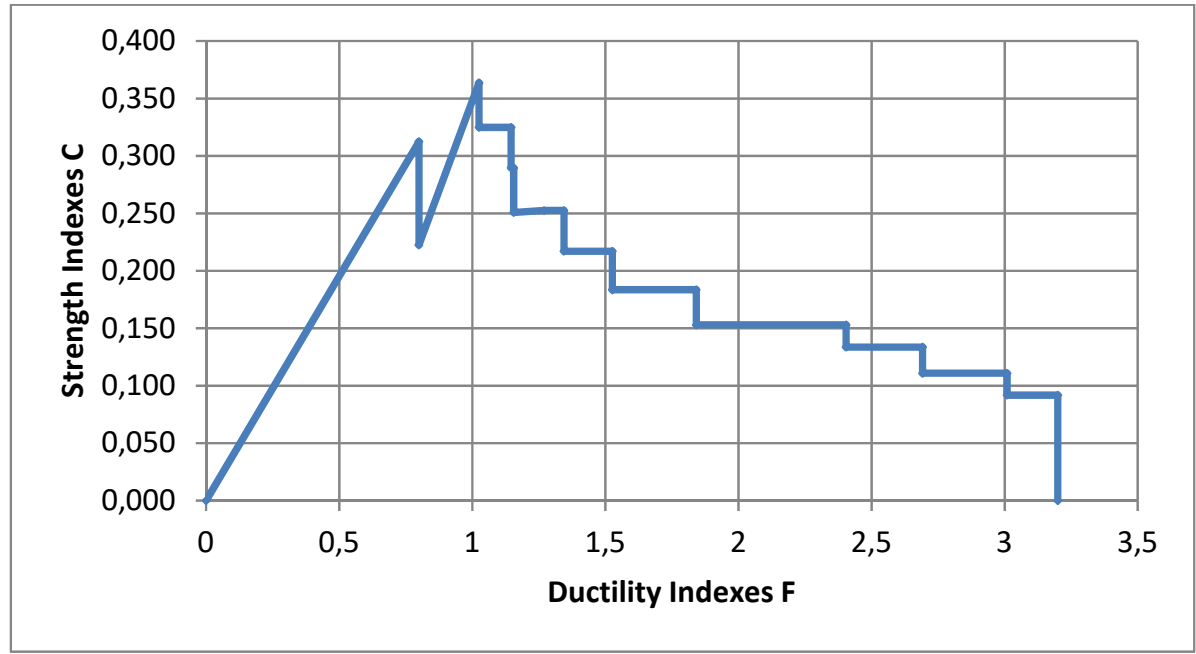

b. Relationship between Index C and F Index in East-West Direction

Fig. 3. Graph of Relationship between C and F Index

Decreasing the strength index can be a possible reason why the building collapsed when the major quake struck. Furthermore, at the ductility index of 1.03, the building collapsed again by reducing the strength index to 0.332 . The building continues to collapse the column until all columns collapse at the ductility limit of 3.2 .

\subsection{Mitigation efforts}

In the earthquake-prone area for reinforced concrete buildings, the quality of concrete K-300 (fc' $25 \mathrm{MPa}$ ). The floor is recommended to be used in the diameter of the minimum stroke is reinforcement screw diameter 10 $\mathrm{mm}$ (D10) and Rainwater drain pipes should not be entered into the column because it will reduce the column cross-section so that the column strength will also decrease. Based on SNI 2847:2013 [9], the length of the main reinforcement of the beam to the column is $12 \mathrm{~d}$ with a curvature of $90^{\circ}$. Long overlapping on a major reinforcement connection of $40 \mathrm{~d}$. The length of the stirrups latch is $6 \mathrm{~d}$ with a curve of $135^{\circ}$ [8]. The distance between the columns in the building should not be too large for the building to become more rigid so it is expected to withstand the earthquake load.

\section{Conclusion}

Based on the results of the analysis and evaluation of the Tadulako University Faculty of Law building according to The Standard for Seismic Evaluation Of Existing Reinforced Concrete Building, 2001 (The Japan Building Disaster Prevention Association, 2005) [7] the second level calculation method, it can be concluded : 1. The lateral strength index of the Tadulako University Faculty of Law building north-south is 0.264 . In the north-south direction, some of the columns experienced shear collapse because there were brick walls which can be translated to the short columns with a net height of $1.27 \mathrm{~m}$. Most of the columns in the north-south direction are quite ductile because they have a ductility index 3.2. 2. The lateral strength index of the Tadulako University Faculty of Law building east-west direction is 0.364 . Few columns in the east-west direction have a ductility index 3.2. 


\section{References}

1.Agus. dan Maidiawati, Perbandingan Kapasitas Seismik Gedung Beton Bertulang dengan dan tanpa pengaruh Dinding Bata. Padang : Institut Teknologi Padang, In Indonesia language (2017)

2.Akbar, F. A. Tugas Akhir Analisis Kontribusi Dinding Batu Bata terhadap Kekuatan Lateral Gedung Beton Bertulang (Studi Kasus Gedung Perkuliahan Institut Teknologi Padang). Padang : Institut Teknologi Padang. In Indonesia language (2017)

3.Earthquake Engineering Research Institute, Learning from Earthquakes, The Mw 7.6 Western Sumatra earthquake of September 30, 2009, EERI Special Earthquake Report (2009)
4.Liza, N M., Maidiawati., dan Tanjung, J., Proc. 1st Andalas Civil Engineering National Conference; Padang (2014)

5.Maidiawati, Agus, Jurnal Teknik Sipil ITB 23 (2016)

6.Maidiawati, Yasushi Sanada DOI :

10.1002/eqe.2787 (2016)

7.The Japan Building Disaster Prevention Association (JBDPA), English Version, 1st, Standard for seismic evaluation of existing reinforced concrete buildings, 2001 (2005)

8. Badan Standardisasi Nasional Persyaratan Beton Struktural untuk Bangunan Gedung SNI2847:2013. Jakarta (2013) 